\title{
Papers
}

\section{Organisational buying and sales administration in the retail sector}

Received (in revised form): 16 November 2007

\section{Rajagopal}

is Professor of Marketing at Monterrey Institute of Technology and Higher Education (ITESM), Mexico City Campus, and Fellow of the Royal Society for Encouragement of Arts, Manufacture and Commerce, London. He has been listed with biography in Who's Who in the World, 2007. He holds a doctoral degree from Ravishankar University, India, and has been conferred the membership (levelII) of Mexican National System of Researchers. He teaches various topics of marketing in graduate, doctoral executive development programmes of the Institute. Dr Rajagopal held key positions in many premier management institutes in India including Administrative Staff College of India.

\section{Abstract}

This study has been conducted in Mexico, and discusses the impact of sales territory design and compensation on salespeople as predictors of performance of sales unit effectiveness in the retailing sector. The factors affecting the performance of sales force through balanced supervisory control, cognitive measures and coordination pattern of task performance in the team have been examined, and managerial implications have been derived for optimising the performance of the sales force in the paper. The findings of the study show that the balance between territory designing and incentive pays affects the overall performance of sales tasks performed by the field sales teams. The sales territory design also largely influences the level of performance both directly and indirectly through its relationship with salespeople's behavioural performance. Discussions in the paper also argue that behaviour control is a consistent predictor of salespeople's performance and effectiveness of the sales units. This indicates the importance of proactively monitoring, directing and evaluating salespeople by the managers.

\section{Rajagopal}

Department of Marketing, Business Division Monterrey Institute of Technology and Higher Education, ITESM Mexico City Campus 222, Calle del Puente, Tlalpan DF 14380 , Mexico Tel: +525554832251 Fax: +525554831341 E-mail: rajagopal@itesm.mx Web: http://www.geocities.com/ prof_rajagopal/homepage.html

\section{Keywords:}

organisational buying, sales force organisation, task administration, outcome performance, retailing, sales unit effectiveness

Journal of Retail and Leisure Property (2008) 7, 3-20. doi:10.1057/palgrave.rlp.5100080; published online 21 December 2007

\section{INTRODUCTION}

Selling is an art largely associated with the behavioural skills of the sale personnel of an organisation. Today, selling is performed using scientific methods of product presentation, advertising and various approaches drawn to 
take the customer into confidence. There are three categories of selling tasks sales generation, sales support and missionary work. Sales generation is the creative task of helping the customer to make a purchase decision. It is concerned with after-sale service. Missionary work is undertaken by a salesperson to stimulate demand to help the distributors (Rajagopal 2007a,b). Salespeople play a key role in the formation of long-term relationships with business partners including buyers and suppliers. As the primary link between the buying and the selling firm, they have considerable influence on a buyer's perceptions of a seller's reliability and the value of a seller's services, and consequently the buyer's interest in continuing the relationship. Buyers often have greater loyalty to salespeople than they have to the firms employing the salespeople, as salespeople develop buyers' perceptions (Weitz and Bradford, 1999). Sales management is a continuous process in a firm. The more a company learns about the sales process, the more efficient it becomes at selling, and the higher the sales yield. As the sales yield increases, the sales learning process unfolds in three distinct phases including initiation, transition and execution. Each phase requires a different size and type of sales force and represents a different stage in a company's production, marketing and sales strategies (Leslie and Holloway, 2006).

Effective management of sales force typically requires both planning and action to deliver powerful aspiration, establishing performance measuring and rewarding systems to reinforce specific goals of sales force and developing mind-sets of salespeople by creating a sense of shared responsibility in performing tasks. Although companies devote considerable time and money to administer their sales forces, it is necessary to focus management strategies on how the structure of the sales force needs to be closely associated with the performance indicators of a firm's business. Firms must consider the relationship between the differing roles of internal salespeople and external selling partners, the size of the sales force, its degree of specialisation, and how salespeople share their efforts among different customers, products and activities. These variables are critical because they determine how quickly the sales force of a firm responds to market opportunities, influences the performance of sales people and affects the revenues, costs and profitability of the firm (Zoltners et al., 2006). The task of a salesperson changes over the course of the selling process. Different abilities are required in each stage of the sale including identifying prospects, gaining approval from potential customers, creating solutions and closing the deal. Success in the first stage, for instance, depends on the salesperson acquiring precise and timely information about opportunities from contacts in the marketplace. Managers often view sales as a set of stereotype activities that begins with prospecting and terminates with closing the deal. But in practice it is a diligent task that involves a variety of conflicts and high risk. Hence, sales performance requires effective administration in a phased manner to resolve conflicts and ambiguities during the negotiation and transactional process.

Administering control measure to field sales force has become a major performance guiding tool in many business firms. Industrial sales organisations largely implement direct management control and influence the activities of employees, leading towards improving their efficiency 
(Anderson and Oliver, 1987; Darr, 2003; Eisenhardt, 1985; Ouchi, 1979). The extent monitoring of sales managers, directing, evaluating and rewarding activities in an organisation intend to guide sales force behaviour through management control processes to achieve favourable results to the organisation and the employees (Anderson and Oliver, 1987). Management control is thus recognised as an important performance indicator of the task performed by the salespeople (Cravens et al., 1993; Oliver and Anderson, 1994).

Result-oriented performance control and market volatility are positively related to new product-selling performance. The effect of sales force adoption on selling performance is stronger where outcome-based control is used and where the firm provides information on the background of the new product to salespeople through internal marketing (Hultink and Atuahene-Gima, 2000). It has been observed that salespeople who simultaneously exhibit commitment and effort will achieve higher levels of new product-selling performance. The sales performance in an international context has emerged from significance managerial consideration in view of growing globalisation and the need to sustain competitive advantage (Anderson, 1996; Magrath, 1997; Samiee and Roth, 1992). Not much research attention has been paid, however, to sales management control beyond developed countries (Money and Graham, 1999), notwithstanding recognition of the critical role of the sales manager in international selling (DeCarlo et al., 1999; Honeycutt and Ford, 1995).

\section{OBJECTIVES OF THE STUDY}

This study discusses the impact of territory design on overall sales performance in reference to the underlying rationale of management control, incentive pay and territory design as predictors of performance and sales unit effectiveness, and attempts to examine the relationships between incentive pay and management control and their impact on the performance of the salespeople. The study has been carried out in Mexico in reference to the four major industrial segments including consumer goods, consumer durables, healthcare products and consumer services, where salespeople are deployed in multinational companies. The independent role of monitoring, directing and evaluating activities in combination with incentive compensation as they relate to important salesperson and organisation consequences has also been analysed in this paper. The critical success factors for improving the performance of sales force through balanced supervisory control, cognitive measures and coordination pattern of task performance in the team have also been examined and managerial implications have been derived for optimising the performance of the sales force. The discussions in the paper also emphasise the rationale of improving managerial understanding of sales management control initiatives and their impact on salesperson and profit optimisation in the retail sector.

\section{REVIEW OF LITERATURE AND HYPOTHESES FRAMEWORK}

\section{Business-to-business sales for retail sector}

The liberal environment of the self-service stores for merchandise decisions, service quality and learning about competitive brands are the 
major attributes of retail self-service stores (Babakus et al., 2004). The retail self-service stores offer an environment of three distinct dimensions of emotions, for example, pleasantness, arousal and dominance. The retail self-service stores operate on a market size effect and a price-cutting effect (Konishi, 1999). Managerially, the multi-brand testing process allows the firm to forecast the impact of the new product introduction on the market shares of competing brands (including those marketed by the firm) at both the aggregate and the segment level. Hence, the firm can use the results to measure segment-specific cannibalisation and switching effects; in addition, it can identify segment-specific adoption patterns for achieving organisational sales. Importantly, the method allows the sales people to choose customised marketing mix strategies for different segments after allowing for the effects of competitive retaliation (Sharan et al., 2007).

On a tactical level, managers need to consider the optimum spread of customers on a matrix of sales attractiveness and market coverage. Besides market demand, managers also need to consider planning differentiation with large product portfolios operating in volatile markets that are governed by the asymmetric behaviour of retail organisations. In addition, the complexity of market, channel and supply networks makes supply chain planning more intricate (Rajagopal, 2007b). The strength of supplier/customer relationships is again measured by applying a mix of objective, judgmental or subjective factors that include:

- Length of the relationship

- Importance of the customer

- Friendship

- Cooperation in product development

- Social distance.

Benefits are calculated by taking the revenue from the sales to the buying organisation (gross value of sales minus the commission paid) and subtracting from it the direct costs, pseudo-direct costs (the costs that could be attributed to groups of similar customers and therefore apportioned accordingly) and indirect costs (Rajagopal, 2005).

\section{Territorial control and effectiveness}

Sales territory design is also considered as a particularly important managerial variable, which has received little analytical attention in the traditional literature, but that appears to be an important influence on the effectiveness of the sales operation (Rajagopal, 2007b). It has been argued that organisational effectiveness is determined by sales force outcome performance and behavioural performance, as well as by the use of a behaviour-based control approach. Although conventional theory has suggested that behaviour performance and outcome performance result from different stimuli, behaviour-based control is positively associated with both behaviour performance and outcome performance (Piercy et al., 1998). The competitive environment in sales also affects the performance of salespeople in a given territory. A study of sales force working in the pharmaceutical companies in UK and Ireland explores 
how changes in the nature of the customer and the competitive environment are impacting the way managements are structuring the work process and the nature of skills required (Lloyd and Newell, 2001).

The territory design is a major determinant of salespeople's opportunity to perform well, and their ability to earn incentive pay where incentives are linked directly to territory-level individual performance (Grant et al., 2001). It has been observed that organisations may not define salespeople' territories based on mutually exclusive geographical areas. Moreover, the effective sales organisations place more emphasis on their sales territory design, and, additionally, their sales forces show significant differences in both personal characteristics and performance dimensions. Salespeople in the more effective sales units display higher levels of intrinsic and extrinsic motivation, sales support orientation and customer orientation. Both salesperson behaviour and outcome performance were rated higher by managers in the organisations with more effective sales units (Baldauf et al., 2002). Experienced sales managers understand that poor territory designs will have a negative impact on salesperson morale, result in inadequate market coverage and complicate management evaluation and control. Several factors beyond the control of the salesperson often guide the territory design decision including the size of the sales force, buying power of the accounts, geographical dispersion of accounts, time required to service each account and competitive intensity (Churchill et al., 2000).

\section{Compensation, control and effectiveness}

Compensation management is becoming increasingly more difficult for organisations to control because sales employees want more and more. Managers need to find out what sales employees want and give it to them in a way that is fair and specific. Being specific in compensation and incentive plans is becoming the new method for managers to follow, at the same time promoting a team atmosphere among sales employees. The study reveals that compensation management of commissioned sales employees does not point to one best method, but managers are encouraging sales employees to work as a group and not against each other. This would create confidence among employees, towards enhancing the work environment and increasing the quality and quantity of sales (Shipley and Kleiner, 2005). Analytical sales force compensation research offers only limited answers to sales managers who try to devise effective compensation plans, because it often rests on restrictive assumptions, and it considers only simple compensation plan structures.

In practice, sales managers need to predict how alternative and relatively complex compensation schemes would affect sales revenues and profits, as well as their likely impacts on sales force morale and turnover. This is why they typically obtain key salespeople's prior reactions to a new scheme, or pre-test the new plan on a limited scale. These procedures, however, may not provide accurate long-run predictions, and they can be applied to only one or two schemes at a time (Darmon, 1997). In particular, individual-level variables such as career stage and risk preferences moderate the relationship between pay mix and valence for the reward, expectancy perceptions and instrumentality 
perceptions. Managers need to acknowledge that certain salespeople respond positively to fixed salary plans while others respond positively to incentive (Pappas and Flaherty, 2006). Firms must pay more attention to early employment experiences. New salespersons need training in order to feel competent and able to meet company-mandated and/or personal objectives. Salespeople have primary contact with the organisation via their immediate sales manager and need to feel like they are fairly rewarded for their efforts. It is important to build strong relations at the area manager level (Liu, 2007).

Financial compensation has long been held as the primary motivator for salespeople. Effectiveness in motivating salespeople, however, may vary due to the large disparities in pay schemes across countries (Rouzies et al., 1999). Sales managers also use formal controls like output and process controls to develop the salespeople's trust in their benevolence (Kwaku and Li, 2006). The selling skills are determined by the degree of experience of the salesperson and the effectiveness of training while the adaptive selling techniques are related to increased performance (Johlke, 2006). Firms should be able to apply the time-based philosophy of revenue management to their sales forces. To do so it is required to have a revision in the way most sales divisions traditionally have viewed salesperson time. Hence, a different type of proposed measure, revenue per available salesperson hour, is proposed to better integrate the value of the salesperson's time as a factor in sales potential and revenue calculation (Siguaw et al., 2003). The sales unit effectiveness is an overall evaluation of outcomes (eg sales, profit contribution) of the sales unit for which the field sales manager is responsible (Churchill et al., 2000). Evaluating the effectiveness is important since it provides an indication of the performance of the manager's sales unit.

\section{Personality factors}

The process of meeting the responsibilities of sales managers in the direct supervision of assigned salespeople describes the control parameters. Generally, a field sales manager may have the responsibility for some salespeople, who constitute the sales unit. In the process of behaviour control, the activities of monitoring, directing and evaluating sales persons, the efforts of sales managers are devoted to a greater extent as compared to the result-oriented control (Anderson and Oliver, 1987). It has been observed through empirical investigations that the method of compensation and control system are important determinants of ethical behaviour while the age of the salesperson also proves to be a significant antecedent of ethical behaviour. However, education may not be significantly related to the behaviour and control process in the sales management. Additionally, a salesperson's ethical behaviour leads to lower levels of role conflict and higher levels of job satisfaction, but not to higher performance (Ramon and Munuera, 2005; Stewart and Nandkeolyar, 2006).

The behaviour of a salesperson is an important predictor of salesperson and sales organisational consequences in developed country studies (Babakus et al., 1996; Piercy et al., 1999). These studies examine control from the perspective of the field sales manager, which is the focus of our 
research. The study of Deshpande and Farley (1998) evidenced from research investigating the consequences of market orientation that the relationships found in developed countries are also relevant in developing countries. The external and internal environment of a company and personality traits affect the decision making of salespeople. Internal communication and the choice of a control system especially affect ethical decision making. It has been observed that informal internal communication affects the personality traits while the control system influences the ethical climate of the salespeople. Ethical climate and salespeople's personality traits also affect the ethical decision making (Verbeke et al., 1996). In fact, the study shows that ethical decision making can be influenced by management. A few studies have found significant relationships between personal and organisational variables such as job experience, closeness of supervision, performance feedback, influence in determining standards and span of control and the amount of role conflict and ambiguity perceived by salespeople. It was found that idealised influence behaviour of salespersons positively influences customer trust, which, together with individualised consideration of salespersons, in turn influences customer commitment. It was also found that the joint effect of both customers' trust and individualised considerate behaviour of the salesperson is greater than each alone on customer's relationship commitment (Jayakody and Sanjeewani, 2006). Other studies relate personal characteristics to variations in motivation by showing that salespeople's desires for different job-related rewards (eg pay, promotion) differ with such demographic characteristics as age, education, family size, career stage or organisational climate (Chonko et al., 1992). The salesperson's expectancy, instrumentality and valence perceptions are not directly under the sales manager's control. But they can be influenced by things the sales manager does, such as how he or she supervises the salesperson or rewards the individual. Since the salesperson's motivation strongly influences performance, the sales manager must be sensitive to how various factors exert their impact (Dubinsky et al., 1994).

The sales results typically emerge from the performance of the salesperson and this issue is receiving increasing attention among the multinational companies. This may be evidenced from research in several countries that indicates that sales managers are concerned with the team and customer relationship-building activities of salespeople as well as their sales results (Corcoran et al., 1995). Outcomes are certainly important, but managers also need to consider the behaviour (inputs) of the salesperson, which is instrumental in guiding the sales results. Another study investigating 104 senior sales managers, who were asked to assign importance ratings to a large number of performance factors evidences that managers ranked almost all the behaviour-based performance factors higher than outcome factors (Morris et al., 1991). Both the salesperson's job behaviour and psychological well-being may be affected if there are perceptions of role ambiguity or conflict or if these perceptions are inaccurate. There is a good deal of evidence, for example, that high levels of both perceived ambiguity and conflict are directly related to high mental anxiety and tension and low job satisfaction. In addition, the salesperson's feelings of uncertainty and conflict and the 
actions taken to resolve them can have a strong impact on ultimate job performance (Singh, 1993). Salespeople in a firm are influenced by sales drivers to reach a high outcome performance in a given region and time. Sales drivers include territory design, compensation, scope of assigned task and cultural interaction in the market.

\section{FRAMEWORK OF HYPOTHESES}

Organisational commitment and sales territory design are significantly related to sales force performance and the study highlights the growing emphasis on building long-term, collaborative buyer-seller relationships that favour the use of behaviour-based control systems in many sales management situations, and suggests a new agenda for management attention in improving sales force effectiveness. The importance of designing effective sales territory is widely supported in the process of organisational restructuring (Bailey, 1989). Despite this importance, the impact of sales territory designs on salesperson and organisational consequences has not gained significant research attention. There is a significant relationship between the different behavioural attributes of work-related activity-work withdrawal behaviours, organisational retaliation behaviours and sales force task performance (Ntayi, 2005). The role of designing effective sales territories in the multinational sales organisation, however, is growing substantially, which includes challenges towards integrating the local market differences in sales infrastructure and other competitive market attributes. Hence, the following hypotheses has been framed:

$\mathbf{H}_{1(\mathbf{a})}$ : Territory design satisfaction is the strongest predictor of behaviour performance in Mexico.

$\mathbf{H}_{1(\mathbf{b})}$ : The tasks assigned in the designated territory, incentive pay and balanced supervisory control provide higher confidence to the salespeople.

It has been observed that the effect of the various layers of a marketoriented culture on the attitudes and behaviours of sales-force personnel stimulate competitive performance. The market-oriented values affect role conflict, role ambiguity, organisational commitment and job satisfaction, and that market-oriented norms have a weak effect on the customer orientation of the salesperson. The level of compensation paid by the firms to sales people also affects the market-oriented value and behavioural performance (Farrell, 2005). The decision of the management of a company determines the proportion of incentive pay in total compensation, which may be described as the rewarding dimension of the sales forces in a control process. It operates independently from managers' monitoring, directing and evaluating activities, and needs to be assessed separately in management practice (Lawler, 1990). Incentive compensation as an essential sales management responsibility may be reorganised accordingly. Agarwal (1993) proposes that reward systems should be a critical point of focus for future international sales 
management studies. Ryals and Rogers (2005) discuss the state of variable pay compensation plans for sales people in business-to-business markets and, in particular, review proposed methods for rewarding key account managers. They argue that only the companies that have a portfolio approach to sales pay, with pay reflecting the type of customer and the skills required to manage the relationship, will achieve appropriate motivation and productivity.

$\mathbf{H}_{2}$ : Compensation, degree of behavioural satisfaction and outcome performance are interrelated, which lead to the effectiveness of the sales units.

Managers consider management control and pay as related, and yet distinct forms of control (Churchill and Pecotich, 1982). Determining the level of fixed salary and incentive payment policies is an important sales management decision. Extensive organisational studies on reward systems support the proposal that compensation is an important, strategic management decision variable that operates independently of other forms of management control (Lawler, 1990).

The above-mentioned hypotheses have been framed considering the relevance of the discussion in various research studies in reference to major variables including behavioural dimensions of salespeople, implications of compensation on task management and overall performance of the sales units in competitive markets. The relevance of the referred literature in framing hypotheses and deriving a theoretical construct for analysing data has been discussed in Table 1.

\section{STUDY DESIGN}

\section{Sample size and data collection}

This study is based on a primary investigation in reference to the practices followed in sales force administration in Mexico. A sample of 258 respondents has been covered under the study categorising in equal proportion into three broad areas that include type of sales force, type of product market and type of sales operations. Data were collected by the graduate students as they also had the advantage of being working managers. The modalities of data collections involved telephone contacts, mailing of questionnaires and company visits to arrange questionnaire completion. Data collection was concentrated on companies in two cities of Mexico - Mexico City and Toluca. The measures used in the study design, as exhibited in Appendix A, comply with the questions asked from the respondents during the data collection.

Initially, a focus group discussion of a representative sample from selected industries was carried out to assess the responsibility of direct supervision of salespeople in industrial selling situations and the sale administration process in general. Based on the process flow in sales administration, major variable segments were identified keeping in view the objectives of the study. Accordingly, pre-coded questionnaires were developed for the study and administered to the respondents. Besides 
Table I: Relevance and inference of various research contributions in the study

\begin{tabular}{|c|c|c|c|}
\hline \multirow[t]{2}{*}{ Thrust area of research study } & \multirow[t]{2}{*}{ Contributors } & \multicolumn{2}{|c|}{ Application of referred contributions in this study } \\
\hline & & $\begin{array}{l}\text { Framing } \\
\text { hypotheses }\end{array}$ & $\begin{array}{l}\text { Inferring analytical } \\
\text { results }\end{array}$ \\
\hline $\begin{array}{l}\text { Defining sales concepts and performance } \\
\text { measure modeling }\end{array}$ & $\begin{array}{l}\text { Rajagopal (2006a), Rajagopal (2007a,b, 2006b) } \\
\text { Ofek, } 2002\end{array}$ & $\mathrm{H}_{2}$ & $\begin{array}{l}\text { Performance of sales people, customer } \\
\text { relationship, shifts in selling process }\end{array}$ \\
\hline $\begin{array}{l}\text { Relationship of sales people with } \\
\text { customers and large accounts }\end{array}$ & Weitz and Bradford (1999), Zoltners et al. (2006) & $\mathrm{H}_{2}$ & Behavioural and outcome performance \\
\hline $\begin{array}{l}\text { Sales Process Management and its role } \\
\text { in optimising sales unit efficiency }\end{array}$ & $\begin{array}{l}\text { Leslie and Holloway (2006), Farrell (2005), } \\
\text { Ryals and Rogers (2005) }\end{array}$ & $\begin{array}{l}\mathrm{H}_{\mathrm{l}(\mathrm{a})} \\
\mathrm{H}_{\mathrm{l}(\mathrm{b})}\end{array}$ & $\begin{array}{l}\text { Sales territory designing and efficiency of } \\
\text { sales units }\end{array}$ \\
\hline $\begin{array}{l}\text { Performance control process in } \\
\text { administering sales teams }\end{array}$ & $\begin{array}{l}\text { Hultink and Atuahene-Gima (2000), Ramon and } \\
\text { Munuera (2005), Rajagopal (2006c), Singh (1993) }\end{array}$ & $\begin{array}{l}\mathrm{H}_{1(\mathrm{a})} \\
\mathrm{H}_{2}\end{array}$ & $\begin{array}{l}\text { Measuring behavioural satisfaction and } \\
\text { outcome performance among the sales teams }\end{array}$ \\
\hline Sales technology and networking & Lapierre and Skelling (2005) & $\mathrm{H}_{2}$ & $\begin{array}{l}\text { Enhancements in sales over the transition from } \\
\text { conventional to innovative products }\end{array}$ \\
\hline $\begin{array}{l}\text { Territory designing and enhancing } \\
\text { performance of sales units in the } \\
\text { competitive markets }\end{array}$ & $\begin{array}{l}\text { Piercy et al. (1998), Grant et al. (200I), } \\
\text { Ntayi (2005) }\end{array}$ & $\begin{array}{l}\mathrm{H}_{\mathrm{I}(\mathrm{a})} \\
\mathrm{H}_{\mathrm{l}(\mathrm{b})}\end{array}$ & $\begin{array}{l}\text { Territory design as an indicator to improve } \\
\text { performance of sales units in the market }\end{array}$ \\
\hline $\begin{array}{l}\text { Behavioural, motivation and training } \\
\text { perspectives of sales people }\end{array}$ & $\begin{array}{l}\text { Baldauf et al. (2002), Liu (2007), } \\
\text { Verbeke et al. (1996) }\end{array}$ & $\begin{array}{l}\mathrm{H}_{1(b)} \\
\mathrm{H}_{2}\end{array}$ & $\begin{array}{l}\text { Task management among sales teams and } \\
\text { balanced supervisory control }\end{array}$ \\
\hline $\begin{array}{l}\text { Compensation and incentive pay as } \\
\text { behavioural indicators to enhance } \\
\text { performance of sales people. }\end{array}$ & $\begin{array}{l}\text { Shipley and Kleiner (2005), Pappas and } \\
\text { Flaherty (2006), Darmon (1997), } \\
\text { Kwaku and Li (2006), Lawler (1990) }\end{array}$ & $\begin{array}{l}\mathrm{H}_{\mathrm{l}(\mathrm{b})} \\
\mathrm{H}_{2}\end{array}$ & $\begin{array}{l}\text { Compensation, handling tasks, motivation, } \\
\text { behavioural satisfaction and outcome } \\
\text { performance }\end{array}$ \\
\hline
\end{tabular}

questions with pre-coded options, some open-ended questions were also administered separately for qualitative assessment of the responses. The content analysis was performed to summarise the open-ended questions using software QSR NVivo2. This software has powerful tools for combining subtle coding with qualitative linking, shaping and modelling qualitative information. The analysis of qualitative responses has largely helped in deriving appropriate managerial implications of the study. The questionnaires were initially drafted in English and later translated into Spanish for use in Mexico. The questionnaires have been translated from English to Spanish using the literal translation and transposition techniques. In translating some questions, the technique of equivalence or reformulation has been used to give a correct sense to the sentence.

Data were collected from 280 respondents equally spread from all four categories of industries including consumer goods, consumer durables, industrial products and consumer services on the identified variables. Accordingly, questionnaires were administered to 70 respondents in each category of industry. Filled-in responses were carefully examined and 22 responses of 22 samples were eliminated from the study due to inconsistency and paucity of information. Hence, information of 258 respondents was considered for data processing and analysing the results. It has been found that the overall response rate in the survey was 92.14 per cent.

Data collection was carried out through e-mails, telephone contacts and company visits. The survey was pre-tested to ensure that the scale of measurement and variables of the study were well understood by respondents. The major attributes of the sample respondents are exhibited in Table 2. 
Table 2: Attributes of sample design used in the study

\begin{tabular}{llll}
\hline Broad sample areas & Sample attributes & Study region & \\
\cline { 3 - 4 } & & No. of respondents & Percent sample \\
& & $\mathbf{( N = 2 5 8 )}$ & \\
\hline \multirow{2}{*}{ Type of sales force } & Generalist salespeople & 54 & 62.79 \\
& Product specialist & 18 & 20.93 \\
& Customer services & 14 & 16.28 \\
Type of products & Consumer products & 41 & 47.67 \\
& Industrial products & 23 & 26.74 \\
& Consumer services & 10 & 11.64 \\
Type of market operations & 12 & 13.95 \\
& Industrial services & & 20.93 \\
& Business-to-Business & 18 & 48.83 \\
& Retail consumer markets & 42 & 20.93 \\
& Large consumer accounts & 18 & 9.30 \\
\hline & Direct selling personnel & 8 & \\
\hline
\end{tabular}

Table 3: Descriptive statistics of the data used in the study

\begin{tabular}{lccccr}
\hline \multirow{2}{*}{ Measures } & \multicolumn{7}{l}{ Variables of the study } & & \\
\cline { 2 - 6 } & BC & SUE & TD & BP & OP \\
\hline Sample variance & 1.724 & 2.316 & 1.842 & 0.804 & 0.560 \\
Mean & 4.935 & 4.157 & 3.222 & 3.470 & 3.185 \\
Standard error & 0.142 & 0.164 & 0.146 & 0.097 & 0.081 \\
Skewness & -1.122 & 0.031 & -0.388 & -0.661 & 0.351 \\
Sample size & 258 & 258 & 258 & 258 & 258 \\
\hline
\end{tabular}

$\mathrm{BC}=$ Behavioural Control; $\mathrm{SUE}=$ Sales Unit Effectiveness $\mathrm{TD}=$ Territory Design $\mathrm{BP}=$ Behavioural Performance; $\mathrm{OP}=$ Outcome Performance.

A study conducted with culturally differentiated sample respondents brings added value to understanding sales management practices. The descriptive statistics of the data used in the study are exhibited in Table 3. The collected data were filtered in reference to reliability test results and were analysed using Excel by applying the structural equations as discussed in the section on Theoretical Motivation.

Data collected from respondents were tested for reliability applying the Cronbach Alpha $(\alpha)$ test. Variables derived from test instruments are declared to be reliable only when they provide stable and reliable responses over a repeated administration of the test. The $(\alpha)$ values were found in the range from 0.77 to 0.94 ( $p>0.01$ two-tailed), within acceptable levels for the individual country samples.

\section{Industry coverage}

Four retail streams in sales were covered while selecting the sample respondents, which include consumer goods, consumer durables, industrial products and consumer services. Customer goods included dairy products, beverages, processed food and products of hygiene and sanitation while consumer durables covered refrigerators, televisions, high-value audio equipments and domestic appliances. The sample of respondent engaged in selling industrial products covered Polyethylene terephthalate $^{1}$ (PET) products for storage of food, beverage and edibles, 
mobile phone accessories, household medical equipment such as blood pressure monitors and electro domestic appliances. Consumer services belonged to the banking and insurance industry in both the countries.

\section{RESULTS AND DISCUSSIONS}

It has been observed in the study that the formal controls on the performance of such activities are carried out in 35.2 per cent of companies in the study area. More strictly 'relational' activities, both in an external (ie towards the customers) and an internal (ie towards other members of the sales team) perspective, appear to be very frequently performed by the sales force; nevertheless, customer relationship management and development seem to be far more intensively performed.

Regressions analysis exhibited in Table 4 presents the relationship between the predictors including behaviour control, incentive pay, territory design and consequence of behaviour, sales performance and sales unit effectiveness. The interpretation of regression results exhibited in the above table indicates that territory design has greater significance along with the behavioural control dimensions to achieve the sales unit effectiveness. Satisfaction with territory design clearly emerges as a more important predictor for the sample respondents. Hence, it may be stated that well-designed territories provide salespeople with the opportunity to perform well.

The study revealed that one of the prominent drivers of behaviour performance of salespeople in Mexico is territory design satisfaction. This finding may be linked to the incentive pay and territory design satisfaction that significantly affects the performance of the salespeople. It has been observed during the study that a good territory design reduces inequality perceptions. Hence, the results presented in Table 4 are consistent with hypotheses $\mathrm{H}_{1(\mathrm{a})}$ and $\mathrm{H}_{1(\mathrm{~b})}$.

This suggests that the efforts of managers to improve territory designs may be more important than their monitoring, directing and evaluating activities in driving a salesperson's outcome performance. Among the other variables used in the study, the incentive compensation has an apparent impact on outcome performance in both the countries. One of the more persuasive reasons for these inconsistent relationships is that particular characteristics of salespeople enable them to deal more effectively with some kinds of customers than with others. It has been observed during the study that quantity measures require a detailed analysis of salespeople's call reports, an extensive time utilisation analysis or even solicitation and evaluation of customer feedback on non-selling activities. Once the measurement procedure is set up, however, it is typically conducted with less bias and inconsistency.

Territory design satisfaction has been observed to be the strongest predictor of behaviour performance in Mexico. It is important to recognise that the coefficients mask their individual impact to some extent due to correlations among the predictors. Correlations for all the variables of the countries under study are shown in Table 5.

This result indicates that higher perceived values to assigned tasks in designated territory, incentive pay and balanced supervisory control may provide more confidence to the salespeople. A positive and significant 
Table 4: Standardised regression coefficients for the variables of the study area

\begin{tabular}{ll}
\hline Variables & Measure \\
\hline Intercept & \\
BC & 4.575 \\
TD & $0.683^{* *}$ \\
BP & $0.846^{* *}$ \\
OP & 0.247 \\
$\mathrm{R}^{2}$ & 0.155 \\
\hline
\end{tabular}

p-values $*>0.01$ and $* *>0.001$.

$\mathrm{BC}=$ Behavioural Control; SUE $=$ Sales Unit Effectiveness; $\mathrm{TD}=$ Territory Design; $\mathrm{BP}=$ Behavioural Performance; $\mathrm{OP}=$ Outcome Performance.

Table 5: Correlation matrix of the major variables under study

\begin{tabular}{llrlll}
\hline Variables & \multicolumn{2}{l}{ Correlation coefficients } & & \\
\cline { 2 - 5 } & BC & SUE & TD & BP & OP \\
\hline BC & 1.000 & & & & \\
SUE & $0.466^{*}$ & 1.000 & & & 1.000 \\
TD & 0.116 & 0.270 & 1.000 & 1.000 \\
BP & $0.898^{* *}$ & -0.034 & $0.733^{* *}$ & $0.484^{*}$ & \\
OP & 0.110 & 0.292 & $0.717^{* *}$ & & \\
\hline
\end{tabular}

p-values $*>0.01$ and $* *>0.001$.

$\mathrm{BC}=$ Behavioural Control; $\mathrm{SUE}=$ Sales Unit Effectiveness; $\mathrm{TD}=$ Territory Design; $\mathrm{BP}=$ Behavioural Performance; $\mathrm{OP}=$ Outcome Performance.

relationship among these variables leads to the effectiveness of the sales units in both the countries. Hence, the results of the study lead to conformity of hypothesis $\mathrm{H}_{2}$.

\section{LIMITATION OF THE STUDY}

The study has been conducted in Mexico, which represents a highly diverse work culture emerging from the regional socio-cultural influence. The samples drawn from the cities in Mexico may not be enough to generalise the study results. The questionnaires were translated into Spanish for the respondents in Mexico, which might have conveyed a varied conceptual sense to some extent. The open-ended questions were answered in Spanish and some issues might have been overlooked during transcription of the audio. The study does not indicate as to how behaviour control, percent incentive pay and territory design satisfaction cause changes in the performance and effectiveness consequences.

Instead, the discussion in the study measures the relationship between the predictors and the consequences. To ensure that the data cover a wider spatial and temporal dimensions in the study region, however, the data should be cleansed and filtered with many variability factors affecting the behavioural and control process of the salespeople. Although this research included the most important sales force activities and the most frequently suggested antecedents of customer trust, other potentially relevant variables, such as conflict management skills (Weitz and Bradford, 1999), confidential information sharing and salesperson power within the selling firm (Morgan and Hunt, 1994), have not been considered. 


\section{MANAGERIAL IMPLICATIONS}

The effective management of salespeople is important to managers of international marketing operations spanning multiple countries and simultaneously maintaining a strong behavioural threshold of salespeople for continuously improving the effectiveness of the sales units. The degree of salesperson input and involvement does, however, appear to vary across firms. Multinational pharmaceutical companies generally assign weights to different performance objectives and incorporate territory data when establishing these objectives while most salesperson performance evaluations are conducted by the field sales manager who supervises the salesperson. Some firms, however, involve the manager above the field sales manager in the performance appraisal of salespeople. The behaviour control is a consistent predictor of salespeople's performance and effectiveness of the sales units. This indicates the importance of proactive monitoring, directing and evaluating salespeople by the managers. Sales managers may implement such controls effectively by establishing a coordination, training and feedback process rather than imposing command and control policy.

Sales teams may be organised in view of the territorial attributes such as critical distances, density of customers and location of service providers to improve the extensive coverage of customers spread across the operational area. Managers need to consider the critical factors that significantly contribute to increasing the performance of salespeople towards administering the tasks and achieving results. Such critical factors include interpersonal and communications skills, knowledge of the products, ability to explore the market demand and creativity in administering sales tasks. Performance evaluations for the purpose of identifying salespeople for promotion into sales management positions should focus on criteria related to potential effectiveness as a sales manager and not just current performance as a salesperson. One of the methods that is workable and effective discusses the development sales benchmarking to perform competitively in the market.

The qualitative information provided by the respondents revealed many managerial approaches to balance the task-compensation relationship. It has been revealed that compensation for the salespeople should be a mix of salary and commission policy. Managers may emphasise more on commission-oriented tasks as they are linked with performance. The sales commission plan based on these three principles will reward the company by doing what it is supposed to do and encourage the profitable selling efforts by the sales force. Sales people operate under the gun most of the time.

The training of salesmen should be directed at making them aware of the advantages of adopting relational behaviours and boosting their capabilities and skills preparatory to an effective implementation of such behaviours. The systems for controlling and appraising the sales force may be designed for the long term (Shultz and Good, 2000) and provide incentives for relational behaviours, if behaviour-based control systems are used, and utilise relational performance indicators. The highperformance salespeople have greater commitment to their organisations and their sales managers are more satisfied with their units' sales territory designs. The mangers may need to re-conceptualise the fact that the 
salespeople should shift from a 'hard selling' to a 'smart-selling' approach. The increasing adoption of a relational approach to customers is therefore fostering a deep-going change in the individual skills set and capabilities of the sales force and, farther upstream, a substantial rethinking of company strategies and policies of selection, training, motivation and control of the sales force.

Managers may define clear sales tasks to ensure significant results from the salespeople and evaluate timely performance feedback. A firm may focus on administering sales activities in four major processes including territory-target-based deployment of sales force, efficiency in managing client account, working with improved information systems and minimising field-level task conflicts. Hence, limiting the number of accounts for each salesperson may work out as a good option to improve the efficiency of sales activities in the market. Field sales managers may be encouraged to adapt management by objectives, performance appraisal and monthly reviews to encourage their salespeople to do their work effectively. Some companies, however, fail to coordinate salespeople's efforts with other customer-facing teams and while operating at crosspurposes, these functions conflict over roles and resources jeopardising the relationship with customers. To correct such misalignments, it is necessary to match sales management practices with strategic priorities of the firm and allow effective coordination among customer-facing teams to enable seamless service for customers.

\section{CONCLUSIONS}

The study reveals the balance between territory designing and incentive pay in performing sales activities in developing countries that affects the overall performance of sales tasks. The incentive pay, however, is normally based on salespeople' outcomes, and is apparently not accomplishing this objective. It may be appropriate for the managers to consider a review of incentive plan designs for improving the sales unit effectiveness. There is no apparent negative impact, however, of relatively high levels of behaviour control in combination with high incentive pay. The work environment is largely governed by territorial tasks for the salespeople. Sales territory design has a large effect on sales organisation effectiveness both directly and indirectly through its relationship with salespeople's behavioural performance. Collecting and processing territory and account information are major aspects of a salesperson's task and to a large extent salespeople's effectiveness depends on the amount and quality of the market information available to them. Although they are not always easy to disentangle, these information gathering and processing activities, on the one hand, and the effective contact time devoted to selling to clients and prospects, on the other, compete for the limited time resources available to a salesperson.

\section{Note}

1 Polyethylene terephthalate is a thermoplastic polymer resin of the polyester family and is used in synthetic fibres; beverage, food and other liquid containers; thermoforming applications; and engineering resins often in combination with glass fibre. 


\section{References}

Agarwal, S. (1993). Influence of formalization in role stress, organizational commitment and work alienation of salespersons: A cross-national comparative study. Journal of International Business Studies. 24(4), 715-739.

Anderson, R.E. (1996). Personal selling and sales management in the new millennium. Journal of Personal Selling and Sales Management. 16(4), 17-32.

Anderson, E. \& Oliver, R.L. (1987). Perspectives on behavior-based versus outcome-based sales force control systems. Journal of Marketing. 51, 76-88.

Babakus, E., Bienstock, C.C. \& Van Scotter, J.R. (2004). Linking perceived quality and customer satisfaction to store traffic and revenue growth. Decision Sciences. 35, 713-737.

Babakus, E., Cravens, D.W., Grant, K., Ingram, T.N. \& LaForge, R.W. (1996). Investigating the relationships among sales management control, sales territory design, salesperson performance, and sales organization effectiveness. International Journal of Research in Marketing. 13(4), 345-363.

Bailey, E.L. (1989). Getting closer to the customer, in Research Bulletin, Vol. 229, The Conference Board, Inc, New York.

Baldauf, A., Cravens, D.W. \& Grant, K. (2002). Consequences of sales management control in field sales organizations: A cross-national perspective. International Business Review. 11(5), 577-609.

Chonko, L., Tanner, J.F. \& Weeks, W.A. (1992). Selling and sales management in action: reward preference of salespeople. Journal of Personal Selling and Sales Management. 13, 65-72.

Churchill, G.A. \& Pecotich, A. (1982). A structural equation investigation of the pay satisfactionvalence relationship among salespeople. Journal of Marketing. 46(Fall), 114-124.

Churchill, G.A., Ford, N.M., Walker, O.C., Johnston, M.W. \& Tanner, J.E. (2000). Sales Force Management, 6th edn, Irwin, Chicago, IL.

Corcoran, K.L., Peterson, L.K., Baitch, D.B. \& Barren, M.E. (1995). High Performance Sales Organizations: Creating Competitive Advantage in the Global Marketplace, Irwin, Chicago, IL.

Cravens, D.W., Ingram, T.N., LaForge, R.W. \& Young, C.E. (1993 October). Behavior-based and outcome-based salesforce control systems. Journal of Marketing. 57, 47-59.

Darmon, R.Y. (1997). Predicting the long-run profit impact of a contemplated sales force compensation plan. Journal of the Operational Research Society. 48(1), 1215-1225.

Darr, A. (2003). Control and autonomy among knowledge workers in sales: An employee perspective. Employee Relations. 25(1), 31-41.

DeCarlo, T.E., Rody, R.C. \& DeCarlo, J.E. (1999). A cross national example of supervisory management practices in the sales force. Journal of Personal Selling and Sales Management. 19(Winter), 1-14.

Deshpande, R. \& Farley, J.U. (1998). Measuring market orientation: generalization and synthesis. Journal of Market Focused Management. 2(September), 213-232.

Dubinsky, A.J., Kotabe, M., Lim, C.U. \& Michaels, R.E. (1994). Differences in motivational perceptions among US, Japanese and Korean sales personnel. Journal of Business Research. 30(2), 175-185.

Eisenhardt, K.M. (1985). Control: Organizational and economic approaches. Management Science. 31(February), 134-149.

Farrell, M. (2005). The effect of a market-oriented organizational culture on sales-force behavior and attitudes. Journal of Strategic Marketing. 13(4), 261-273.

Grant, K., Cravens, D.W., Low, G.S. \& Moncrief, W.C. (2001). The role of satisfaction with territory design on the modification, attitudes, and work outcomes of salespeople. Journal of the Academy of Marketing Science. 29(2), 165-178.

Honeycutt, E.D. \& Ford, J.G. (1995). Guidelines for managing an international sales force. Industrial Marketing Management. 24(2), 135-144.

Hultink, E.J. \& Atuahene-Gima, K. (2000). The effect of sales force adoption on new product selling performance. Journal of Product Innovation Management. 17(6), 435-450.

Jayakody, J.A.S.K. \& Sanjeewani, W.M.A. (2006). The impact of salesperson transformational leadership behavior on customer relationship marketing behavior: a study of the Sri Lankan corporate banking sector. The International Journal of Bank Marketing. 24(7), 461-474.

Johlke, M.C. (2006). Sales presentation skills and salesperson job performance. Journal of Business and Industrial Marketing. 21(5), 311-319.

Konishi, H. (1999). Concentration of competing retail stores, Boston College, Working Papers in Economics, No. 447.

Kwaku, A.G. \& Li, H. (2006). The effects of formal controls on supervisee trust in the manager in new product selling: Evidence from young and inexperienced salespeople in China. Journal of Product Innovation Management. 23(4), 342-358.

Lapierre, J. \& Skelling, J. (2005). Sales force control system in high-tech contexts: Do environment and industry matter? Journal of Business and Industrial Marketing. 20(6), 297-306. 
Lawler, E.E. (1990). Strategic Pay: Aligning Organizational Strategies and Pay Systems, Jossey-Bass, San Francisco, CA.

Leslie, M. \& Holloway, C.A. (2006). The sales learning curve. Harvard Business Review. 84(7-8), $114-123$.

Liu, C.M. (2007). The early employment influences of sales representatives on the development of organizational commitment. Employee Relations. 29(1), 5-15.

Lloyd, C. \& Newell, H. (2001). Capture and transfer: Improving the performance of the pharmaceutical sales representatives. International Journal of Human Resource Management. 12(3), 464-483.

Magrath, A.J. (1997). From the practitioner's desk: A comment on personal selling and sales management in the new millennium. Journal of Personal Selling and Sales Management. 17(1), 45-47.

Money, R.B. \& Graham, J.L. (1999). Salesperson performance, pay, and job satisfaction: Tests of a model using data collected in the United States and Japan. Journal of International Business Studies. 30(1), 149-172.

Morgan, R.M. \& Hunt, S.D. (1994). The commitment-trust theory of relationship marketing. Journal of Marketing. 58(3), 20-38.

Morris, M.H., David, D.L., Allen, J.W., Avila, R.A. \& Chapman, J. (1991). Assessing the relationship between performance measures, managerial practices, and satisfaction when evaluating the sales force. Journal of Personal Selling and Sales Management. 11(Summer), 25-35.

Ntayi, J.M. (2005). Work ethic, locus of control and sales force task performance. Journal of African Business. 6(1-2), 155-176.

Ofek, E. (2002). Customer Profitability and Lifetime Value, Harvard Business School, Note, August, 1-9 (Publication reference 9-503-019), Harvard Business School Press, Boston, MA.

Oliver, R.L. \& Anderson, E. (1994). An empirical test of the consequences of behavior- and outcome-based control systems. Journal of Marketing. 58(4), 53-57.

Ouchi, W.Z. (1979). A conceptual framework for the design of organizational control mechanisms. Management Science. 25(September), 833-847.

Pappas, J.M. \& Flaherty, K.E. (2006). The moderating role of individual-difference variables in compensation research. Journal of Managerial Psychology. 21(1), 19-35.

Piercy, N.F., Cravens, D.W. \& Morgan, N.A. (1998). Sales force performance and behavior-based management processes in business-to-business sales organizations. European Journal of Marketing. 32(12), 79-100.

Piercy, N.F., Cravens, D.W. \& Morgan, N.A. (1999). Relationships between sales management control, territory design, sales force performance and sales organization effectiveness. British Journal of Management. 10(2), 95-111.

Rajagopal (2005). Analysis of customer portfolio and relationship management models: bridging managerial gaps. Journal of Business and Industrial Marketing. 20(6), 307-316.

Rajagopal (2006a). Measuring customer value and market dynamics for new products of a firm: An analytical construct for gaining competitive advantage. Global Business and Economics Review. 8(3-4), 187-204.

Rajagopal (2006b). Measuring customer value gaps: An empirical study in Mexican retail markets. Economic Issues. 11(1), 19-40.

Rajagopal (2006c). Leisure shopping behavior and recreational retailing: A symbiotic analysis of marketplace strategy and consumer response. Journal of Hospitality and Leisure Marketing. $15(2), 5-31$

Rajagopal (2007a). Sales management in developing countries: A comparison of managerial control perspectives. Journal of Asia Pacific Business. 8(3), 37-61.

Rajagopal (2007b). Stimulating retail sales and upholding customer value. Journal of Retail and Leisure Property. 6(2), 117-135.

Ramon, S. \& Munuera, J.L. (2005). Determinants and consequences of ethical behavior: An empirical study of sales people. European Journal of Marketing. 39(5-6), 473-495.

Rouzies, D., Segalla, M. \& Besson, M. (1999). The impact of cultural dimensions on sales force compensation, Working Paper, No. 670, HEC Business School, France, pp. 1-45.

Ryals, L.J. \& Rogers, B. (2005). Sales compensation plans - one size does not fit all. Journal of Targeting, Measurement and Analysis for Marketing. 13(4), 354-362.

Samiee, S. \& Roth, K. (1992). The influence of global marketing standardization on performance. Journal of Marketing. 56(2), 1-16.

Sharan, J., Jedidi, K. \& Jamil, M. (2007). A multi-brand concept-testing methodology for new product strategy. Journal of Product Innovation Management. 24(1), 34-51.

Shipley, C.J. \& Kleiner, B.H. (2005). Compensation management of commissioned sales employees. Management Research News. 28(2-3), 2-10.

Shultz, R.J. \& Good, D.J. (2000). Impact of consideration of future sales consequences and customer oriented selling on long term buyer-seller relationship. Journal of Business and Industrial Marketing. 15(4), 200-215. 
Siguaw, J.A., Kimes, S.E. \& Gassenheimer, J.B. (2003). B to B sales force productivity: Applications of revenue management strategies to sales management. Industrial Marketing Management. 32(7), 539-551.

Singh, J. (1993). Boundary role ambiguity: facets, determinants and impacts. Journal of Marketing. 57(2), 11-31.

Stewart, G.L. \& Nandkeolyar, A.K. (2006). Adaptation and intra-individual variation in sales outcomes: Exploring the interactive effects of personality and environmental opportunity. Personnel Psychology. 59(2), 307-332.

Verbeke, W., Ouwerkerk, C. \& Peelen, E. (1996). Exploring the contextual and individual factors on ethical decision making of salespeople. Journal of Business Ethics. 15(11), 1175-1187.

Weitz, B.A. \& Bradford, K.D. (1999). Personal selling and sales management: A relationship marketing perspective. Journal of the Academy of Marketing Science. 27(2), 241-254.

Zoltners, A.A., Sinha, P. \& Lorimer, S.E. (2006). Match your sales force structure to your business life cycle. Harvard Business Review. 84(7-8), 80-89.

\section{APPENDIX A}

\section{Measures Used In The Questionnaire For Data Collection From The Sales}

\begin{tabular}{|c|c|c|}
\hline $\begin{array}{l}\text { Information } \\
\text { cluster }\end{array}$ & Scale & Measures \\
\hline $\begin{array}{l}\text { Behaviour } \\
\text { Control (BC) }\end{array}$ & $\begin{array}{l}\mathrm{I}=\text { Not at all } \\
7=\text { to a large extent }\end{array}$ & $\begin{array}{l}\text { Monitors daily performance of salespeople } \\
\text { Active participation in the on-job training of sales force } \\
\text { Guiding sales force in improving their performance } \\
\text { Assess quality of tasks performed by the sales people } \\
\text { Plan and evaluate professional development activities } \\
\text { Informally shares time with the sales people in a routine way }\end{array}$ \\
\hline $\begin{array}{l}\text { Sales Unit } \\
\text { Effectiveness } \\
\text { (SUE) }\end{array}$ & $\begin{array}{l}1=\text { Very weak } \\
5=\text { Excellent }\end{array}$ & $\begin{array}{l}\text { Productivity in reference to sales volume } \\
\text { Trend in reference to market share } \\
\text { Growth in contribution towards profitability of the firm } \\
\text { Performance in reference to time, target and territory management } \\
\text { Contributions towards customer relationship and value }\end{array}$ \\
\hline $\begin{array}{l}\text { Territory } \\
\text { Designing (TD) }\end{array}$ & $\begin{array}{l}\text { I=fully dissatisfied } \\
7=\text { Highly satisfied }\end{array}$ & $\begin{array}{l}\text { Quantum of accounts in the territory } \\
\text { Workload distribution among the salespeople in the territory } \\
\text { Number of small but significant retail accounts in the region } \\
\text { Trend of sales productivity in the territory } \\
\text { Number of calls per day in the territory } \\
\text { Overall size of the sales territory }\end{array}$ \\
\hline $\begin{array}{l}\text { Behavioural } \\
\text { Performance (BP) }\end{array}$ & $\begin{array}{l}1=\text { Very poor } \\
7=\text { Outstanding }\end{array}$ & $\begin{array}{l}\text { Awareness about the company policies on sales and services } \\
\text { Operations and applications in sales and services of products } \\
\text { Communications and flow of directives with salespeople } \\
\text { Skills on selling solutions and customer relations } \\
\text { Functional flexibility with subordinate sales staff } \\
\text { Innovative and adaptive sales approaches } \\
\text { Customer centred sales planning } \\
\text { Post-sales customer care } \\
\text { Handling customer complaints and objections in the sales territory }\end{array}$ \\
\hline $\begin{array}{l}\text { Outcome } \\
\text { Performance (OP) }\end{array}$ & $\begin{array}{l}\text { I=Very Poor } \\
5=\text { Very Good }\end{array}$ & $\begin{array}{l}\text { Scope for improving the market share } \\
\text { Developing strategies and skills for high tech-high value products } \\
\text { Swift sales operations among the distributors and retailers } \\
\text { Locating new accounts and developing prospect plans } \\
\text { Augmenting the profit contribution by territorial sales } \\
\text { Managing strategic business units and profit centre approach }\end{array}$ \\
\hline
\end{tabular}

